\title{
SUSCEPTIBILITY OF Duponchelia fovealis Zeller (Lepidoptera: Crambidae) TO Bacillus thuringiensis BERLINER (BACILLACEAE)
}

\author{
PETRUCCI, Kharen Priscilla de Oliveira Salomão ${ }^{1}$ \\ PRATISSOLI, Dirceu ${ }^{1}$ \\ DAMASCENA, Alixelhe Pacheco ${ }^{1}$ \\ ARAUJO JUNIOR, Luis Moreira de ${ }^{1}$ \\ CARVALHO, José Romário de ${ }^{1}$ \\ RODRIGUES, Higor de Souza ${ }^{2}$ \\ BUENO, Regiane Cristina Oliveira de Freitas ${ }^{3}$
}

Recebido em: 2019.09.26 Aprovado em: 2020.03.26 ISSUE DOI: $10.3738 / 1982.2278 .3698$

SUMMARY: The use of biological control agents come in response to the need for a more developed and sustainable agriculture. Duponchelia fovealis Zeller (Lepidoptera: Crambidae) was reported causing serious problems for strawberry culture in the State of Espírito Santo. Because it is a recent pest, there is no registration of products for its control. Among the entomopathogen bacterium Bacillus thuringiensis Berliner stands as a promising method of control, since it is specific and is not harmful to man. This study aimed to evaluate the efficiency of two products formulated the basis of B. thuringiensis Agree ${ }^{\circledR}(B$. thuringiensis var. aizawai GC-91) and Dipel ${ }^{\circledR} \mathrm{WP}$ (B. thuringiensis var. kurstaki HD-1) on Duponchelia fovealis Zeller for their use in pest management programs. Bioassays were performed in microtubes containing acrylic trays, filled with artificial feed. Each tube was inoculated on the feed, $70 \mathrm{ml}$ of each commercial product at a concentration $1 \times 10^{8}$ spores $\cdot \mathrm{mL}^{-1}$. Subsequently, 50 larvae of each stage of development, were individually wrapped, forming a particular treatment. Mortality was assessed daily until day 7. The estimated lethal concentration $\left(\mathrm{LC}_{50}\right)$ to the stage of increased susceptibility was also performed. In view of the results it was observed that the initial stage of development, showed higher mortality at $90 \%$ and $80 \%$ for Agree ${ }^{\circledR}$ and Dipel ${ }^{\circledR} \mathrm{WP}$, respectively products. The products were effective in controlling $D$. fovealis in the first stage of development, however we observed greater virulence Agree $^{\circledR}$ product, which required a lower dose to achieve the $\mathrm{LC}_{50}$.

Keywords: Entomopathogens. Integrated Pest Management. Microbial control.

\section{SUSCEPTIBILIDAD DE Duponchelia fovealis Zeller (Lepidoptera: Crambidae) A Bacillus thuringiensis BERLINER (BACILLACEAE)}

RESUMEN: El uso de agentes de control biológico responde a la necesidad de una agricultura más desarrollada y sostenible. Se informó que Duponchelia fovealis Zeller (Lepidoptera: Crambidae) causó serios problemas para el cultivo de fresas en el Estado de Espírito Santo. Debido a que es una plaga reciente, no hay registro de productos para su control. Entre la bacteria entomopatógena Bacillus thuringiensis Berliner se erige como un método prometedor de control, ya que es específico y no es dañino para el hombre. Este estudio tuvo como objetivo evaluar la eficiencia de dos productos formulados a partir de B. thuringiensis Agree ${ }^{\circledR}$ (B. thuringiensis var. Aizawai GC-91) y Dipel® WP (B. thuringiensis var. Kurstaki HD-1) en Duponchelia fovealis Zeller para su uso en programas de manejo de plagas. Los bioensayos se realizaron en microtubos que contenían bandejas acrílicas, llenas de alimento artificial. Cada tubo se inoculó en la alimentación, $70 \mathrm{ml}$ de cada producto comercial a una concentración de $1 \mathrm{x}$ 108 esporas - mL-1. Posteriormente, 50 larvas de cada etapa de desarrollo, fueron envueltas individualmente, formando un tratamiento particular. La mortalidad se evaluó diariamente hasta el día 7. También se realizó la concentración letal estimada (CL50) en la etapa de mayor susceptibilidad. En vista

\footnotetext{
${ }^{1}$ Nucleus for Scientific and Technological Development in Phytosanitary Management (NUDEMAFI), Agronomic Sciences Center, Federal University of Espirito Santo, Rua Alto Universitário, s/n, Caixa Postal 16, CEP: 29500-000, Alegre-ES, Brazil.

${ }^{2}$ Department of Entomology, Federal University of Viçosa, CEP: 36570-000, Viçosa-MG, Brazil.

3Department of Crop Protection, School of Agriculture, São Paulo State University, Campus of Botucatu, Universidade Estadual Paulista "Júlio de Mesquita Filho" - UNESP. Av. Universitária, 3780 - Altos do Paraíso, Fazenda Experimental Lageado - Botucatu/SP - CEP 18610-034, Brazil.
} 
de los resultados, se observó que la etapa inicial de desarrollo mostró una mayor mortalidad al $90 \%$ y $80 \%$ para los productos Agree® y Dipel ${ }^{\circledR}$ WP, respectivamente. Los productos fueron efectivos en el control de $D$. fovealis en la primera etapa de desarrollo, sin embargo, observamos una mayor virulencia del producto Agree®, que requirió una dosis más baja para lograr la CL50.

Palabras clave: Entomopatógenos. Manejo integrado de plagas. Control microbiano.

\section{INTRODUCTION}

The strawberry culture has been highlighted as one of the cultures with greatest importance in the state of Espirito Santo, Brazil (BALNINO et al., 2006). However, a new species has been found of insect-pest, Duponchelia fovealis, which causes great losses. A polyphagia pest that can occur in approximately 38 families of host plants characterizes this insect. The Espirito Santo region is known for strawberry culture (Fragaria $\mathrm{x}$ ananassa Duch.) in high and low tunnels. Nonetheless, there are no registrations of chemical or biological products for its control (FORNAZIER et al., 2012).

However, in search for a sustainable agriculture and a higher concern for the environment requires change in conventional production methods. Biological insecticides have been used for over 50 years in the country (BOBROWSKI et al., 2003) and this use has been the alternative to control insect-pest harmful to agriculture. Among biological agents are the entomopathogenic bacteria Bacillus thuringiensis which has shown promising results in other countries where this insect-pest is present (POLANCZYK, 2003; VIANA, et al., 2009).

Studies conducted in California showed that products based on B. thuringiensis have been used as selective control method for D. fovealis (BETHKE; VANDER MEY, 2010). Bioinsecticides such as Dipel ${ }^{\circledR}$, which contains strains of $B$. thuringiensis, are suggested as larvicide in European regions (MURPHY, 2008), such as Germany where reports have shown $B$. thuringiensis to be efficient in the reduction of $40 \%$ in $D$. fovealis population (JÄCKEL; KURZHALS, 1995).

Looking to improve technology that are promising in the managemente of $D$. fovealis, this study aims to assess the susceptibility of Duponchelia fovealis to commercial formulated products based of B. thuringiensis (Bt): Agree ${ }^{\circledR}, B$. thuringiensis var. aizawai GC-91, and Dipel $\mathrm{WP}^{\circledR}$, B. thuringiensis var. Kurstaki lineage HD-1, aiming on its use for integrated pest management. 


\section{MATERIAL AND METHODS}

The study was conducted at the Nucleus for Scientific and Technological Development in Phytosanitary Management (NUDEMAFI) at the Agronomic Sciences Center at the Federal University of Espirito Santo, Alegre, ES (Brazil) in a climatized room adjusted to temperatures of $25 \pm 1{ }^{\circ} \mathrm{C}, 60 \pm 10 \%$ relative humidity and photophase of $12 \mathrm{~h}$.

Obtaining and Multiplying Duponchelia fovealis Zeller (Lepidoptera: Crambidae)

Obtainment and collection of $D$. fovealis was conducted in strawberry fields in the Espirito Santo region where caterpillars were isolated and sent to the entomology department at NUDEMAFI, where they were kept and fed until they turned into pupae.

The methods used for breeding were developed at NUDEMAFI where: adult $D$. fovealis were kept in PVC tubes $(200 \mathrm{~mm} \times 20 \mathrm{~cm}$ ) coated on the inside with paper on a styrofoam base also covered in paper, the superior extremity of the tube closed with a voile cloth. To feed the adults, each tube contained $5 \mathrm{~mL}$ of honey water solution at $10 \%$ covered with cotton and paper. The laying was collected daily and kept in plastic container until eggs were hatched into caterpillars. Following, the newly hatched caterpillars were transferred to clear plastic containers with $16 \mathrm{~cm}$ diameter and $10 \mathrm{~cm}$ height, with perforated lids to allow gas exchanges. The bottom of the containers were covered with wavy paper with screens in order to avoid contact between the food and the bottom. On top of the screen, thin slices of artificial feed adapted with soybean meal, wheat germ and sugar were offered to $D$. fovealis. This feed was used to feed the caterpillars during their larvae stage. The insects remained in those containers until pupae period was reached.

\section{Susceptibility of $\boldsymbol{D}$. fovealis to Bacillus thuringiensis formulates}

The following $B$. thuringiensis $(\mathrm{Bt})$ based commercial formulates were used: Agree $^{\circledR}$, B. thuringiensis var. aizawai GC-91, and Dipel $\mathrm{WP}^{\circledR}$, B. thuringiensis var. Kurstaki lineage HD-1. For each product, the solution was dilluted in destilled water at a rate of $1 \mathrm{~mL}$ of suspension per 100 times distilled water, and the concentration of spores determined by Neubauer ${ }^{\circledR}$ chamber readings. After reading measurements, the concentration of each product was adjusted to $1 \times 10^{8}$ spores $\cdot \mathrm{mL}^{-1}$. 
The pathogenicity assays for each product were conducted separately in trays made up of acrylic microtubes of $3.0 \times 2.0 \mathrm{~cm}$ (height $\mathrm{x}$ diameter), where $2 \mathrm{~mL}$ of artificial feed were added, using during the breeding phase for D. fovealis. Later, $70 \mu \mathrm{L}$ of each formula in a $1 \times 10^{8} \mathrm{~mL}^{-1}$ concentration spores was inoculated in the acrylic microtubes containing the artificial feed and, following the evaporation of excess humidity, 50 caterpillars of each phase were individually placed in the acrylic tubes. The phases were determined in previous assays through measurements of the cephalic capsule (data not presented). Each group of 10 caterpillars was considered as one repetition, with a total of five repetitions per treatment (product). The same procedure was conducted for a control at each phase, using distilled water on the feed.

The experimental matter was kept in climatized chamber $\left(25 \pm 1{ }^{\circ} \mathrm{C}, \mathrm{RH} 70 \pm\right.$ $10 \%$ and photophase $12 \mathrm{~h}$ ) and assessed $12 \mathrm{~h}$ after insect inoculation to verify if there was death due to caterpillar inoculation. Posterior assessments were conducted daily until the 7th day to verify lethal effect of those isolates over the caterpillars.

The experiment was conducted in a casual design in subdivide parcels of $2 \mathrm{x} 4 \mathrm{x}$ 2 [B. thuringiensis based products $\mathrm{x}$ Phases (stages) $\mathrm{x}$ repetitions (experiments)], and data were transformed by $\sqrt{(x+1)}$. The data were subject to variance analysis and the means were compared by Tukey test $(\mathrm{p} \leq 0.05)$. To confirm efficiency of the test, it was performed at two different moments. The corrected mortality was calculated in relation to the control by the Abbott formula (1925) using Assistat software.

\section{Estimated lethal concentration $\left(\mathbf{L C}_{50}\right)$}

Both tested products in the susceptibility experiment were used for $\mathrm{LC}_{50}$ estimation. For each product, spaced equally distant concentrations were used through a logarithm scale. Therefore, the $\mathrm{LC}_{50}$ for Agree ${ }^{\circledR}$ products were composed by 444 and 445 caterpillars at first and second repetitions respectively, and for Dipel product 446 caterpillars were used at both repetitions. Controls used distilled water over feed. The experiment was conducted in climatized chamber $\left(25 \pm 1{ }^{\circ} \mathrm{C}\right.$, RH $70 \pm 10 \%$ and photophase 12h) and assessed daily until the 7th day to verify lethal effect over the caterpillars. Lethal concentrations were estimated using Probit analysis using Polo Pc software. 


\section{RESULTS AND DISCUSSION}

Corrected mortality of $D$. fovealis was not significantly different for phase combinations (parcels) and products (subparcels) among the experiments (subsubparcels) $(\mathrm{F}=1.7988 ; \mathrm{p}=0.1673)$ (Table 1). Even though there was little variation between the values, on repetitions (experiments) the effect of B. thuringiensis based products over the different larvae stages was similar.

In the different combinations of stages and products it was verified significant differences $(\mathrm{F}=3.402 ; \mathrm{p}=0.034)$ (Table 2). Independent from product, there was difference in mortality at the different development stages, higher at younger stages. For Agree $^{\circledR}$ and Dipel ${ }^{\circledR}$ products, the first development stage showed higher susceptibility to B. thuringiensis with 95.88 and $86.76 \%$ mortality, respectively.

Table 1. Corrected mortality of Duponchelia fovealis at different stages of larvae development on artificial feed and two Bacillus thuringiensis based products, Agree ${ }^{\circledR}$ and Dipel ${ }^{\circledR}$, with corresponding concentration of $1 \times 10^{8}$ spores $\cdot \mathrm{mL}^{-1} \cdot\left(25 \pm 1{ }^{\circ} \mathrm{C}, \mathrm{RH}\right.$ $70 \pm 10 \%$ and photophase 12h) in two repetitions (Experiments).

\begin{tabular}{|c|c|c|c|}
\hline \multirow{2}{*}{ Products } & \multirow{2}{*}{ Stages } & \multicolumn{2}{|c|}{ Experiments $^{N S}$} \\
\hline & & 1 & 2 \\
\hline Agree & 1 & 93.82 & 97.96 \\
\hline Agree & 2 & 63.60 & 57.60 \\
\hline Agree & 3 & 55.15 & 57.76 \\
\hline Agree & 4 & 8.65 & 1.14 \\
\hline Dipel & 1 & 89.78 & 83.80 \\
\hline Dipel & 2 & 49.45 & 69.28 \\
\hline Dipel & 3 & 29.80 & 32.90 \\
\hline Dipel & 4 & 2.71 & 2.71 \\
\hline $\mathrm{VC} \%-\mathrm{a}^{1}$ & 16.26 & & \\
\hline $\mathrm{VC} \%-\mathrm{b}^{2}$ & 14.95 & & \\
\hline $\mathrm{VC} \%-\mathrm{c}^{3}$ & 14.14 & & \\
\hline$F_{\text {int. axbxc }}$ & 1.7988 & & \\
\hline $\mathrm{DFR}^{4}$ & 32 & & \\
\hline $\mathbf{P}$ & 0.1673 & & \\
\hline
\end{tabular}


${ }^{2}$ Variation coefficient for subparcel (products);

${ }^{3}$ Variation coefficient for subsubparcel (Experiments);

${ }^{4}$ Degrees of freedom of residual for subsubparcel.

Agree $^{\circledR}$ products had similar effects on the mortality of caterpillars at development stages 2 and 3, presenting 60.56 and 56.45\% mortality, respectively (Table 2). On the other hand, Dipel ${ }^{\circledR}$ products resulted in mortality of caterpillars being different at all stages, with $58.95 \%$ at stage 2 and $31.33 \%$ at stage 3 .

Table 2. Susceptibility of Duponchelia fovealis at different stages of larvae development to two Bacillus thuringiensis based products, Agree ${ }^{\circledR}$ and Dipel ${ }^{\circledR}$, with corresponding concentration of $1 \times 10^{8}$ spores. $\mathrm{mL}^{-1}\left(25 \pm 1{ }^{\circ} \mathrm{C}, \mathrm{RH} 70 \pm 10 \%\right.$ and photophase $12 \mathrm{~h}$ ) in two repetitions (Experiments).

\begin{tabular}{|c|c|c|}
\hline \multirow{2}{*}{ Stages } & \multicolumn{2}{|l|}{ Products } \\
\hline & Agree & Dipel \\
\hline 1 & $95.88 \mathrm{aA}^{1}$ & $86.76 \mathrm{aA}$ \\
\hline 2 & $60.56 \mathrm{aB}$ & $58.95 \mathrm{aB}$ \\
\hline 3 & $56.45 \mathrm{aB}$ & $31.33 \mathrm{bC}$ \\
\hline 4 & $4.22 \mathrm{aC}$ & $2.71 \mathrm{aD}$ \\
\hline $\mathbf{F}_{\text {int. axb }}$ & 3.402 & \\
\hline $\mathbf{D F R}^{2}$ & 24 & \\
\hline $\mathbf{P}$ & 0.034 & \\
\hline
\end{tabular}

Around 50,000 B. thuringiensis isolates were identified and currently many laboratory studies in the world have been looking to find isolates with new efficient toxins for pest management (MONNERAT; BRAVO, 2000).

On stage 4 mortality was below $5 \%$ for both products, which may be due to interruption of feeding. During the pre pupae stage the caterpillar does not get fed in order to avoid contamination by products that act through ingestion (FRANCO; BAPTISTA, 2010). In the same context, Bethke and Vander Mey (2010) recommend the $B t$ treatment in newly hatched caterpillars since they are exposed in plants differently from those more development which prefer to be hiding, not feeding themselves with parts that could contain the product. Besides specificity some $B t$ toxines may associate to receptors without the connection being enough to cause the death to the insect. Morandi Filho et al., (2007) when studied the effect of $B$. thuringiensis and organophosphate insecticides on third and fourth stages of 
Argyrotaenia sphaleropa (Meyrick) in laboratory conditions and commercial products, verified that mortality due to the use of $B$. thuringiensis was equivalent to chemical insecticides, being a viable alternative.

Dipel $^{\circledR}$ (Bt Kurstaki HD-1) is the product with higher reach in the world market (POLANCCZYK; ALVES, 2003) and even though it is the most recommended to control D. fovealis, this study showed Agree ${ }^{\circledR}$ as the higher virulence for the pest. According to the same authors, variation in efficacy of products may occur due to factors related or not to the action mode of such pathogen, such as crystal dissolution, activation of protoxin and connection of the active toxin to intestinal epithelium receptors.

To date, no receptors have been identified that are involved in the connection between the toxins Cry of Bt for D. fovealis, however the use of products formulated with $B$. thuringiensis have been reported by many authors in different countries (BETHKE et al., 2013; MURPHY, 2008; Jäckel and Kurzhals, 1995). In literature, Cry toxins $1 \mathrm{Aa}$, Cry $1 \mathrm{Ab}$, Cry 1Ac, Cry 2Aa, Cry 2B relate to the subspecies kurstaki $\left(\right.$ Dipel $\left.^{\circledR}\right)$ and toxins Cry 1Aa, Cry 1Ab, Cry 1Ca, Cry 1Da, Cry 2A6 and Cry 9B to the subspecies aizawai $\left(\right.$ Agree $\left.^{\circledR}\right)$. That diversity isthe determinant for selectivity of insecticide activity, each one at the level of toxicity differentiated for diverse species (GILL, 1995).

Studies reporting susceptibility of Helicoverpa armigera (Hübner) to different Cry toxins indicate that proteins Cry1Ac, Cry1Ab, Cry2A and Cry2B are toxic. However, Cry1Ac is shown to be the most toxic and this could be due to the number of connections and tighter bonds with receptors in the intestine of this insect (VALAITIS, 2011; ESTELA et al., 2004; LIAO et al., 2002; ANGELO et al., 2010). Similarly, it is possible that Cry proteins could be exclusively present in the Agree ${ }^{\circledR}$ product and this can be determinant for higher virulence of $D$. fovealis in this study.

In estimation of lethal concentration $\left(\mathrm{LC}_{50}\right)$ there was increased percentage in mortality of $D$. fovealis caterpillars proportional to the increase in concentration of spores. The assessments were adequate according to the Probit model and presented significant chi-square (significant $\chi^{2}, \mathrm{p}>0.05$ ) (Table 3). Analyzing the confidence intervals it was not possible to determine the difference between experiments with Agree ${ }^{\circledR}$ and Dipel ${ }^{\circledR}$ products. 
The inclinations on the concentration-mortality curve varied between Agree ${ }^{\circledR}$ and Dipel ${ }^{\circledR}$ products. It was observed less inclination with Agree ${ }^{\circledR}(0.34$ and 0.38$)$ when compared to Dipel ${ }^{\circledR}(1.25$ and 1.16). 
Table 3. Estimate of $\mathrm{LC}_{50}$ of two Bacillus thuringiensis based products, Agree ${ }^{\circledR}$ and Dipel $^{\circledR}$ on Duponchelia fovealis in caterpillars at stage 1 of development $\left(25 \pm 1^{\circ} \mathrm{C}, \mathrm{RH}\right.$ $70 \pm 10 \%$ and photophase of $12 \mathrm{~h}$ ) in two repetitions (Experiments).

\begin{tabular}{|c|c|c|c|c|c|c|c|}
\hline $\operatorname{Prod}^{1}$ & $\mathbf{E}^{2}$ & $\mathbf{N}^{3}$ & Inclination $\pm \mathrm{SE}^{4}$ & $\mathrm{LC}_{50}^{5}\left(\mathrm{CI}^{6} 95 \%\right)$ & $\chi^{2(7)}$ & $\mathbf{D F}^{8}$ & $\mathbf{P}^{9}$ \\
\hline \multirow{2}{*}{ Agree } & 1 & 444 & $0.34 \pm 0.050$ & $\begin{array}{l}2.07 \times 10^{5} \\
\left(7.05 \times 10^{4}-4.79 \times 10^{5}\right)\end{array}$ & 5.946 & 7 & 0.546 \\
\hline & 2 & 445 & $0.38 \pm 0.051$ & $\begin{array}{l}1.74 \times 10^{5} \\
\left(1.32 \times 10^{4}-7.67 \times 10^{5}\right)\end{array}$ & 19.026 & 7 & 0.278 \\
\hline \multirow{2}{*}{ Dipel } & 1 & 446 & $1.25 \pm 0.097$ & $\begin{array}{l}8.86 \times 10^{5} \\
\left(5.77 \times 10^{5}-1.35 \times 10^{6}\right)\end{array}$ & 9.0522 & 7 & 0.249 \\
\hline & 2 & 446 & $1.16 \pm 0.089$ & $\begin{array}{l}9.62 \times 10^{5} \\
\left(4.90 \times 10^{5}-1.85 \times 10^{6}\right)\end{array}$ & 19.355 & 7 & 0.249 \\
\hline
\end{tabular}

\footnotetext{
${ }^{1}$ Prod: Bt based products;

${ }^{2}$ E: experiments through time;

${ }^{3} \mathrm{~N}$ : number of observations;

${ }^{4}$ Inclination \pm SE: curve inclination \pm standard error;

${ }^{5} \mathrm{LC}$ : Lethal concentration (spores. $\mathrm{mL}^{-1}$ )

${ }^{6} \mathrm{CI}$ : confidence interval;

${ }^{7} \mathrm{X}^{2}$ : Chi-squared;

${ }^{8} \mathrm{DF}$ : degrees of freedom;

${ }^{9} \mathrm{P}$ : probability.
}

The lethal concentration required to cause $50 \%$ mortality in D. fovealis population varied from $1.74 \times 10^{5}$ to $2.07 \times 10^{5}$ spores $\cdot \mathrm{mL}^{-1}$ of $B$. thuringiensis var. aizawai GC-91 for Agree ${ }^{\circledR}$ and $8.86 \times 10^{5}$ to $9.62 \times 10^{5}$ spores $\mathrm{mL}^{-1}$ of B. thuringiensis var. Kurstaki lineage HD-1 for Dipel ${ }^{\circledR}$.

The differences in toxicity of these products may be related to the composition of the crystals and their toxic potential (POLANCZYK et al., 2000). From a practical stand point, the control of $D$. fovealis using $B$. thuringiensis may be considered effective and therefore an important tool in integrated pest management for strawberry culture. It must be highlighted that the behavior of these formulated products in field conditions may be different depending on biological and abiotic factors, which could alter levels of virulence obtained in laboratory assays (SANTOS JUNIOR et al., 2009, BRAVO et al., 2007). 


\section{CONCLUSION}

It was verified that the products Agree $^{\circledR}$ and Dipel $^{\circledR}$ are promising in the management of $D$. fovealis at the first stage of development, nonetheless more virulence was observed with Agree ${ }^{\circledR}$ which needed a lower dose to reach LC $_{50}$. Therefore, the results showed pathogenicity and virulence of both formulated from B. thuringiensis to D. fovealis, but studies in semi-field or field conditions are necessary to validate their use for phytossanitary management programs.

\section{ACKNOWLEDGEMENTS}

The authors appreciate the Conselho Nacional de Desenvolvimento Científico e Tecnológico (CNPq), Fundação de Amparo à Pesquisa e Inovação do Espírito Santo (FAPES) and Coordenação de Aperfeiçoamento de Pessoal de Nível Superior (CAPES) for financial support.

\section{REFERENCES}

ANGELO, E.; VILAS-BOAS, G.; CASTRO-GOMÉZ, R. Bacillus thuringiensis: Características gerais e fermentação. Semina: Ciências Agrárias, v. 31, n. 4, p. 945958, 2010.

BETHKE, J. A.; OSBORNE, L. S.; STOCKS, S.D.; MEY,B. V.; HODGES, A.C.; SCHUBLE, D. L.; SCHMALE, L. Real and Potential Impact of the European Pepper Moth on Ornamental Plant Production and Agriculture. 2012. Disponível em: <http://cisr.ucr.edu/pdf/saf_proceedings_bethke2012.pdf >. Acesso em: 27 ago. 2019.

BETHKE, L.; VANDER MEY, B. Pest Alert: Duponchelia fovealis. University os California Cooperative Extension San Diego. 2010. Disponível em: <http://ucanr.org/sites/cetest/files/55177.pdf>. Acesso em: 15 set. 2019.

BRAVO, A.; GILL, S. S.; SOBERÓN, M. Mode of action of Bacillus thuringiensis Cry and Cyt toxins and their potential for insect control. Toxicon, v. 49, n. 4, p. 423-435, 2007.

ESTELA, A.; ESCRICHE, B. \& FERRÉ, J. Interaction of Bacillus thuringiensis toxins with larval midgut bindings sites of Helicoverpa armigera (Lepidoptera: Noctuidae). Applied and Environmental Microbiology, v.70, n. 3, p. 1378-1383, 2004.

FORNAZIER, M. J.; PRATISSOLI, D.; MARTINS, D dos S.; DALVI, L. P; TEIXEIRA, C. P.; SILVA, A. T. da; THOMPSON, E. L.; RODRIGUES, A K.;

PRATES, R. S.; COZER, E.; MOREIRA, J. P. de A.; BECALLI, L.; PAES, J. P. P.; 
TIBURCIO, M. O. Praga exótica no estado do Espírito Santo - Duponchelia fovealis Zeller, 1847 (Lepidoptera: Crambidae). Morango mais saudável - Morando monitorado e rastreado. Vitória. ES. (folder) 2011.

FRANCO, M. C.; BAPTISTA, M. C. Duponchelia fovealis Zeller - nova praga em Portugal. Frutas, legumes e flores. A revista dos profissionais, v. 110, p. 34-35, 2010.

GILL, S. Mechanism of action of Bacillus thuringiensis toxins. Memória do Instituto Oswaldo Cruz, v. 90, v. 1, p. 69-74, 1995.

JÄCKEL, B.; KURZHALS, M. Biologische Bekämpfungsmöglichkeiten von Duponchelia fovealis. In: Deutsche Gesellschaft für allgemeine und angewandte Entomologie. 5. ed. Berlim. 1995. p. 7-7.

LIAO, C.; HECKEL, D.; AKHURST, R. Toxicity of Bacillus thuringiensis insecticidal proteins for Helicoverpa armigera and Helicoverpa punctigera (Lepidoptera:

Noctuidae), major pests of cotton. Journal of Invertebrate Pathology, v. 80, p. 55-66, 2002.

MONNERAT, R. S.; BRAVO, A. Proteínas bioinseticidas produzidas pela bactéria Bacillus thuringiensis: modo de ação e resistência. In: MELO, I. S.; AZEVEDO, J. L. Controle biológico. Jaguariúna: Embrapa Meio Ambiente. 2000. p.163-2000.

MORANDI FILHO, W. J.; BOTTON, M.; GRÜTZMACHER, A. D.; ZANARDI, O. Z. Efeito de Bacillus thuringiensis e inseticidas químicos no controle de Argyrotaenia sphaleropa (Meyrick, 1909) (Lepidoptera: Tortricidae) em videira. Arquivos do Instituto Biológico, v. 74, n. 2, p. 129-134, 2007.

MURPHY, G. An overview of Duponchelia control options. 2008. Disponível em: <http://www.greenhousecanada.com/content/view/1424/38/>. Acesso em: 08 jan. 2019.

POLANCZYK, R.; ALVES, S. Bacillus thuringiensis: uma breve revisão. Agrociência, v. 7, n. 2, p. 1-10, 2003.

POLANCZYK, R.; SILVA, R. F. P. da; FIUZA, L. M. Effectiveness of Bacillus thuringiensis strains against Spodoptera frugiperda (Lepidoptera: Noctuidae). Brazilian Journal of Microbiology. v. 31, p.165-167. 2000.

SANTOS JUNIOR, H.J.G.; MARQUES, E. J.; POLANCZYK, R. A.; PRATISSOLI, D.; RONDELIII, V. M. Suscetibilidade de Helicoverpa zea (Boddie) (Lep.: Noctuidae) a Bacillus thuringiensis Berliner (Bacillaceae). Arquivos do Instituto Biológico, v. 76, n. 4, p. 635-641, 2009.

VALAITIS, A. Localization of Bacillus Thuringiensis Cry1A toxin-binding molecules in gypsy moth larval gut sections using fluorescence microscopy. Journal of Invertebrate Pathology, v. 108, p. 69-75, 2011.

VIANA, C. L. T. P.; DE BORTOLI, S. A.; THULER, R. T.; GOULART, R. M.; THULER, A. M. G.; LEMOS, M. V. F.; FERRAUDO, A. S. Efeito de novos isolados de Bacillus thuringiensis Berliner em Plutella xylostella (Linnaeus, 1758) (Lepidoptera: Plutellidae). Científica, v. 37, n. 1, p. 22 - 31, 2009. 